\title{
15
}

\section{Activist participatory communities in archival contexts: theoretical perspectives}

\author{
Andrew Flinn and Anna Sexton
}

We start this chapter by acknowledging that the label 'activist participatory communities' is a construct that is rooted in what we will describe as the 'institutional gaze'. Our use of this construct as a means to define and understand 'different' forms of archiving is therefore complex and can have positive and negative consequences. In our archival context, which is the place from which both authors speak, the label can be used constructively by archive professionals as a means of acknowledging, seeking to understand, embrace and support archival activities and spaces that occur outside traditional archive structures. However, all processes of defining that position something or someone against an implicitly accepted 'norm' can be problematic. The fixing of the institutionally rooted (and therefore mainstream) archival gaze on the 'other' carries the risk of reinforcing distance, a continual forcing and holding at the margins, as opposed to an embedding into the heart of archival theory and practice.

In writing this chapter, we acknowledge this tension, and rather than adopting the terminology of hierarchies and of 'alternative' and 'other' we agree with views that recognise and embrace the multiplicity of ways of thinking about and ways of doing archiving that coexist in the archival multiverse. ${ }^{1}$ Indeed we write to celebrate the richness of archival spaces and practices that sit alongside the traditional archive institution. We believe that our archive institutions and the associated archive profession is (and will continue to be) enriched and challenged to change through growing exposure to (and collaboration with) the theory, methods, people, spaces, action and outputs that drive the processes of archiving outside the walls of the traditional archive institution.

Both authors embrace postmodern understandings of the archive, and in our teaching of emerging archive professionals we acknowledge the traditions from which the profession has grown, while opening our students up to new and growing currents of thinking, which position archive theory and practice as a pluralistic and dynamic space in which a multiplicity of positions and perspectives coexist. This requires breaking down the traditional power dynamics that exist around archive theory and practice, and challenging the privileging of the 'great' white western men of archival theory and practice, and the governmental and bureaucratic approaches to records and recordkeeping their writings represent, understandings that still pervade and hold so much authority over how young professionals in western (and often non-western) contexts are taught to understand and work with archives. Writing this chapter is part of our ongoing commitment to change and shift these power dynamics, to be part of shaping a field that is inclusive and all-encompassing of diverse approaches to archiving. We see this as important as we are individuals who theorise about the archive, and have responsibilities that extend to teaching new archivists entering the profession. 


\section{Defining activist participatory communities in archival contexts}

Definitions of what constitutes a 'participatory archive' and what constitutes a 'community archive' are fluid and open to constant contestation and debate. From within the archive profession, and its associated academic discourse, the term 'participatory archive' has been associated variously with ideas of the collective creativity of Archives 2.0, the democratisation of mainstream archive decision-making and professional processes via a sharing of authority between archivists and others, and more radically the recognition and crucially the exercising of multiple 'rights, responsibilities, needs and perspectives with regard to the archives'. 2

When mainstream archive institutions are centralised as a focal point, a language around 'participation' develops, which implicitly references a 'handing over' or a 'giving away' of control. In practice what is frequently really on offer is at best a collaboration, a mediated coproduction with, for the most part, the authority and control over the objectives, limits and products of the 'participation' retained by the professional body. This characterisation of participation may involve non-professional or external input to decisions about collecting, appraisal values and description or engaging in highly mediated 'transcription machine' processes, but such advice is frequently only advisory and within processes considered not critical. As a result the final authority of the archivist remains unchallenged and power relations around the archive are largely untransformed. Ersoy's introduction to a volume exploring contemporary participatory and collaborative practices outlines some of the critiques of the continued power imbalances and 'material inequalities that foreground disempowerment' in the application of such rhetoric. ${ }^{3}$ Notions of demarcating boundaries between types of archive process, project or product through labels such as 'mediated', 'less mediated' and 'unmediated' have become a means through which to understand the evolving archive landscape. ${ }^{4}$ Such labels and the use of participatory language must be opened up to critical examination, as the continued centring of the mainstream institution carries a privileging that inevitably reinscribes rather than challenges existing power dynamics.

There is a different perspective on participatory practice, sometimes allied with or informed by 'feminist, critical race, post-colonial and participatory action research and with radical social justice aspirations' aims at producing knowledge towards a radically egalitarian reshaping of society'. ${ }^{5}$ In these cases the focus of the participatory research or activity is either solely undertaken by the 'community' or if a co-production with the community firmly in control of defining the objectives and processes. Thus, this chapter focuses on participation in archival endeavours that are not controlled, enabled and facilitated by professionals but rather conducted on communities' and activists' own terms. From the professional vantage point, these 'unmediated' spaces are most commonly referenced under the umbrella of 'community archives'. Over the last decade, there has been a growing body of literature, written from within and outside professional circles, on what is meant by the term 'community archive'. Notable early definitional markers coming from within UK professional archive practice (including its associated institutions, professional bodies, policymakers, funders and academic communities) were laid down within the UK Archives Taskforce report Listening to the Past, Speaking to the Future, the Community Archives Development Group report The Impact of Community Archives 
and the Museum, Libraries and Archives commissioned report written by Jura Community Archives and the Sustainable Communities Agenda. ${ }^{6}$ These reports sat alongside academic pieces of research by Flinn, Hopkins and Flinn et al. ${ }^{7}$ Each was written with an underlying objective of endorsing the practice of community-based archiving and challenging rarely spoken yet implicit and insidious beliefs within the profession that archiving and related heritage activities outside institutional walls were necessarily 'less than', 'unprofessional' or 'non-archival', and could, therefore, lead to less rigorous, invalid or improper history making. The fact that many independent and community-based archives and associated grassroots knowledge production practices had had a long and productive history did not prevent the condescension and ignorance of the value of the community-based activity that permeated much professional thinking at that time. $^{8}$

In a recent study of the 'amateur', Merrifield describes the narrowness of professional experts whose 'esoteric language sets them apart, gains entry into exclusive professional bodies, onto expert panels, ones strictly off-limits to rank amateurs, unless they're the audience'. ${ }^{9}$ With hindsight the declaration in the UK Archives Taskforce report that 'archives in the community [were] as important to society as those in public collections' was a landmark moment for the UK recordkeeping profession. The fact that it stood out as so important then and now tells us where the profession was at that time in its understanding and appreciation of non-institutionally based archiving and history-making endeavours. ${ }^{10}$ Early contributions to professional archive discourse around the community and participatory archives were therefore written in this context as positioned pieces of advocacy that sought to highlight how archival practice outside mainstream archive institutions in the UK, let alone across the world, exists in multiple forms with a long and rich history, and that the materials arising from these practices are just as significant as those held by mainstream institutional counterparts.

Within an academic discourse, the term 'community archive' is most often used to denote independently organised and run archive initiatives where autonomy from the mainstream is a vital identifying attribute of the initiating group, along with a politically and culturally motivated commitment to actively counter absences, silences, forgetting and misrepresentations relating to a particular group or community in mainstream archives. However in professional archival descriptions, community archive is often used in a much broader sense to include a wide range of archiving and heritage-based initiatives, often local 'communities' but not exclusively so, which might exist either wholly outside the mainstream or semi-inside with some level of input from heritage professionals. ${ }^{11}$ Within the broader definition, there is a recognition that the impetus for the archiving initiative may be either highly politically motivated or less politically charged, more oriented around celebrating a locality, a region, an occupation, a faith or a language with less of an overt or an intervention in direct opposition to mainstream representation. Such broad definitions are embraced, for example, by the Community Archives and Heritage Group in the UK which was first launched in 2009 (growing out of the Community Archive Development Group) as a membership body open to heritage professionals and community members who are active and engaged in this area. ${ }^{12}$ 
Despite this, it is generally unhelpful to see formal public archives and community-based counter-archives as a binary distinction rather than being part of an archiving spectrum, which may share practices and assumptions as well as differences. Moore suggests the communitybased archives might be best viewed as boundary objects that share characteristics with other archives but also reflect on those archives better to understand their workings, weaknesses and impact. ${ }^{13}$ Certainly in the digital environment, digital community archives may offer a more fluid, dynamic and participatory approach to archiving and archives ('dynarchives'), ${ }^{14}$ what Giannachi refers to as Archives 2.0, 3.0 and even 4.0 in contrast to the more fixed (in form and meaning) and closed understanding of Archives 1.0. They embody broader knowledge and culture production processes, which shift engagement from passive consumption to something more actively creative and productive. ${ }^{15}$ Although the terms community archive or communitybased archive have gained widespread currency in the English-speaking world (especially the UK and Ireland, North America and Australia) and have begun to be used elsewhere, including most recently in Korea, China and Thailand and parts of the Middle East, there are many different terms and definitions describing the activity of community-based and participatory archiving. While many of these initiatives employ 'archive' to describe themselves, many do not and refer to themselves as a resource centre or institute, a library or an oral history workshop. It is important to recognise that there is perhaps little difference between these initiatives and some radical community and social movement museums such as District Six museum in Cape Town or the Free Derry Museum, which seek to construct alternative and counter-publics through the display and dissemination of different, community-based histories and memories. ${ }^{16}$

Gilliland and Flinn note that the label 'community archive' remains a slippery and necessarily contested term. ${ }^{17}$ Although many participatory and community-based archiving initiatives that sit outside the walls of the mainstream archival institution self-identify as community archives (because they find it a useful and fitting descriptor of their initiatives), it is fair to suggest that, outside the UK at least, it is a label that has more currency within the institution, profession or academy than it does from within the actual archiving endeavours that the profession chooses to label with the term. There are many initiatives that the institutional gaze fixates on as 'community archives' because we have become increasingly comfortable with the label and the form of archiving that we think it represents. Yet we sometimes label without a proper appreciation of whether the actual community around that initiative chooses to identify themselves with the same terminology. For many independently focused archiving initiatives, the term community archive remains an alien concept or inappropriate ('community' in particular can be seen as reductive and othering), and other descriptors are applied as far more fitting descriptive terms. It is a positive development that 'community archives' has become a recognised descriptor within professional archival circles and by those who self-define as such, part of the process where such endeavours have become more visible, accepted, celebrated, recognised, appreciated and valued from the professional perspective. However, we must bear the dangers of creating labels from the outside looking in constantly in mind when seeking to engage, support and collaborate with archiving initiatives that sit fully or partially outside mainstream spaces. 
While up to this point the 'community archive' label might have been useful in drawing attention to the equal significance of non-professionally sanctioned archiving, theoretical insights offered by Drake have usefully problematised the term, opening up the tensions that exist within the terminology, and highlighting the potentially harmful consequences of its use. ${ }^{18}$ Drake draws on Ferguson, Tsing and Cooper to question the creation of a dichotomy between local and global and community and state, which can 'entrench power, rather than revealing and distributing it' and can obscure 'the flows and exchanges between the proximate and approximate'. ${ }^{19}$ Drake argues that these dichotomies persist because they enable a continual reinforcement of vertical power structures where the centre and the margins remain polarised. Drake breaks these dichotomies apart using compelling examples of how in online archival spaces, what might be termed local projects specific to a geographical area are increasingly unbounded through broader accessibility to a geographically dispersed range of potential participants. He also highlights how all archives serve communities, including state-led archives. Drake calls for 'community archive' practitioners and those who theorise about 'community archives' to 'name the stakes of our work more candidly and clearly'. For archive initiatives that sit within what we have begun to homogenise under the 'community archive' label, a clearer definition might occur through the adoption (or perhaps reassertion) of a more precise language around the nature of the archiving endeavour and what is at stake. For many, this may involve the assertion of the political claims underpinning the archive initiative, alongside the liberatory intentions.

Certainly, a more precise use of language might help to distinguish between those who focus on a meaning-making in place and belonging (however physically geographically dispersed the participating communities might be) in their actions from those with more explicitly political transformative aims. However, we should not fall into the trap of condescension and fail to recognise that 'digging where you stand' and actively participating in collecting, researching and telling your own story cannot be a proactive and politically charged process too.

Repeatedly we find ourselves with the problem of categorisation, of externally defining and ascribing characterisations to an almost infinite variety of endeavours. ${ }^{20}$ Given this, is this categorisation a useful process either for the external academic view or for those participating in the activities themselves? Is there utility (political or sustaining) in talking of participatory archives, community archives and a community archives movement? Ultimately are these all just archives, all serving communities (more or less well defined), all with a range of actors participating in the archiving process? The most salient point is that however we describe the activity in which individuals and groups actively and often collectively participate in the process of 'archiving' outside mainstream funded institutions, such participatory and change-oriented practices did not emerge as a result of professional recognition of the term community archives, but have occurred on their own terms for many decades, even centuries. Indeed, such practices could be said to far predate notions of archiving as a professional responsibility.

In rejecting the systemic dangers of inclusion within a professionalising system which represents and reinforces the oppression and injustice faced by communities, Yusef Omowale offers, rather than an accommodation with the professionalised and now 'approved' and 'legitimised' version of archival practice, a vision of community-led and community-based archives in which 'our 
archives have always existed, and our communities have always done archival work' ${ }^{21}$ The sustainability of such archival work is threatened not by this lack of so-called professional practice but by 'being dispossessed of things like our land, our housing, even our health' and will be countered by continuing 'the struggles for justice and sovereignty for all our communities so that we can continue doing the memory work we have been doing from the beginning'.

In employing the term 'activist' along with 'archive' or 'archiving' to define a narrower subset of the broad umbrella term, we are perhaps moving towards more of the precision called for by Drake. The term 'activism' in archival contexts has increasingly gained currency and attention within the professional sphere of archives. This is perhaps best demonstrated by the special issue 'Archiving Activism and Activist Archiving' in Archival Science, which explored the overlaps and distinctions between archives that collect records of activist groups, and the use of archives in an 'activist' mode that seeks to challenge present and future realities and bring about social change and transformation. ${ }^{22}$ When archives are used with 'activist' intentions, voice and agency in and around the archive are invoked to bring about more socially just futures for underrepresented, marginalised and silenced groups. Activist uses of the archive can be undertaken by a range of actors engaging with any given archive including archivists and record creators, and extending out to broad user communities. Bringing together the notion of activism and community archives indicates a form of group engagement in archiving initiatives where the underlying motivation is firmly rooted in a desire to use archiving as a means to speak into present inequity and injustice, with the intention of transforming the status quo. Though again this might be a question of an external academic categorisation as, even more than with the case of the critique of community archives, very few archives explicitly refer to themselves as an activist archive.

Using the term 'participatory' alongside activist and community archives emphasises those groups and initiatives that seek to pay attention to the power dynamics underpinning group participation around the archive. That is those endeavours where participation in 'archiving' is not mediated through systems and structures of professional authority and control. Like, 'community archive' the term 'participatory' is a construct that has gained currency in recent years from a professional vantage point. As explored earlier, this usage has tended to be associated with practices that shared or offered the possibility of sharing the power and authority of the professional archivist over the knowledge production that encircles the archive, and has therefore most commonly been associated with approaches instigated from the mainstream. These 'participatory' practices have come to be understood in professional discourse as a means to open up and democratise professionalised archive management processes including appraisal and selection, ${ }^{23}$ description ${ }^{24}$ and the ongoing evolution of access and use of archive materials, ${ }^{25}$ but usually in ways in which professional control was often at best only shared (rather than relinquished) and in fact often remained unchallenged. The impetus here in professional archival theorising about 'participatory' approaches to archives has been to create new mechanisms and processes for managing and opening up archive collections. This offers the possibility of more sharing of authority between archivists and the communities they serve, in relation to archive collections held in institutional spaces, without fundamentally questioning or undermining that authority. 
However, another thread of thinking about 'being participatory' is articulated from various vantage points and is more intimately rooted in challenging injustice. For example, participatory models are being articulated out of work to address concerns around archival issues and indigenous human rights in the USA, Canada, New Zealand, Australia and other settler-colonial societies where there is a recognition that western archival and legal frameworks on who has the authority to control, disclose, access and use these records restrict the self-determination and freedom of the indigenous communities that these records are about. ${ }^{26}$ This rooting of a 'participatory' approach into specified injustices has been the basis of Sexton's PhD research, which focused on the co-production of a mental health archive with a group of individuals with lived experience of surviving the mental health system. ${ }^{27}$ The online archive created was used by the group as a counterpoint to challenge the Wellcome Library to reflect critically on its archive collecting practices in relation to mental health, where a medical model of diagnosis and intervention is perpetuated and championed through the ongoing predominance of a collecting mandate that selects predominantly institutional and medically focused archive collections. Many parallels can be drawn between emerging praxis in an archival context that seeks to employ participatory techniques to challenge injustice and work undertaken by community activist archives that use methodologies such as community-based research, ${ }^{28}$ anti-oppressive practice, ${ }^{29}$ and the many forms of participatory action research rooted or influenced by critical and emancipatory theories. ${ }^{30}$ Therefore, when we talk about activist community-based endeavours that are 'participatory', we are talking about actors who have an approach to challenging injustice that is also embedded in methods that 'acknowledge that multiple parties have rights, responsibilities, needs and perspectives with regard to archives' and enable a shared authority between and across all those engaged in the archiving endeavour. ${ }^{31}$ This indicates a move away from top-down approaches where history is guarded and controlled by a few central gatekeepers, towards a model of shared control, responsibility and engagement across participating community members.

\section{Activist, participatory community-based archiving: motivations and objectives}

Despite all the above acknowledged problems with external (academic and professional) designation and categorisation, if we can make a case for the utility of identifying and naming an activist, participatory and community-based approach to archiving it is important to try to understand more about what motivates these many and varied initiatives to 'constitute' an archive ${ }^{32}$ or continue the process of archiving, ${ }^{33}$ and what they are seeking to achieve by doing so. We argue that citizen and community archivists running participatory independent, autonomous, community-based archives are frequently (if not always) motivated by a political activism, associated with a range of political campaigns and social movements dedicated to countering the silences, symbolic annihilations and misrepresentations apparent not only in mainstream archives and the 'authorised heritage discourse' but reflects the inequalities of power and representation, and marginalisations in societies as a whole. ${ }^{34}$ It is with these acts of conscious and participatory counter-hegemonic archiving, heritage recovery and archival activism that this definition will now mainly concern itself. 
The motivations that underpin those running participatory archiving and community-based archives are long-standing and fuse a range of traditions of non-professional, non-academic, knowledge production activities. They include local antiquarianism and historical societies, the political struggles around civil and human rights which stimulated interest in the recovery of different pasts, the development and practice of oral history, community research and publishing, collaborative movements such as History Workshop, and online memory and history sharing sites. ${ }^{35}$ In common with community-based archives, all these movements and approaches combined an interest in different historical subjects and voices (those previously absent or underrepresented in the formal historical and heritage narratives) with an understanding of archival and research practice which placed non-professional and non-academic researchers and archivists (alone or in collaboration with others) at the heart of these initiatives.

The Swedish movement 'Gräv där du står' or 'Dig Where You Stand' and the historical research manual published by author and radical journalist Sven Lindqvist was a particularly influential and exemplary instance of this. It fused the non-professional 'amateur' researcher with the political by advocating and indeed setting out a blueprint for, in Lindqvist's case, factory workers to extend their knowledge and control over their working environment through historical research. ${ }^{36}$ Similar manuals aiming at the participatory collecting of resources and the production of 'activist' histories were produced in many countries (including for instance in South Africa in the height of the state of emergency in the 1980s) and relating to a range of national, ethnic, class, gender and other identity-based histories. The work of community and activist education scholars such as Choudry make a case for the importance of learning about the past and using (and creating) archives for successful and effective community and social movement activism. ${ }^{37}$ Choudry and Vally reject the binary distinctions between activism (doing) and learning, instead arguing that most effective activism is underpinned by reflection and learning in many forms including the knowledge of the past and activist experiences. They argue that community archives and community-based history-making activities can be essential components of many social- and community-based movements:

$\langle\mathrm{DQ}>$

Around the world, community and social movement activists have often employed creative and innovative tools and approaches, which include experimentation with pedagogical strategies and practices, as they construct and co-construct, document, recover and preserve histories and ideas. On the other hand, where they exist, such histories and alternative archives are in danger of being lost, for example, as organisations dissolve at times of political, social and economic transition, or as people try to uncover social movement or organising history and ephemera during periods of repression, and among marginalised communities and groups when the maintenance and preservation of documents has sometimes carried great risk. Furthermore, these processes and practices of producing historical resources that are relevant for contemporary struggles can be sites of experimentation, intergenerational learning and exchange, debate, tension, and contestation of ideas and memories. ${ }^{38}$ 
$</ \mathrm{DQ}>$

Although our focus here, as for Choudry and Vally, is on those archives run by activists who overtly seek to contest political power and the structuring of society, we must also acknowledge that there are today a host of other participatory DIY archiving initiatives and 'amateur digital archivists' who wish to document all aspects of life and culture, from popular music and fan culture to gaming and fan fiction, without recourse to professional structures and support. ${ }^{39} \mathrm{As}$ with Stuart Hall's focus on the moment of the African and Asian artists to 'constitute' their archive as an intervention against the marginalisation in existing art histories, ${ }^{40}$ Baker and Collins emphasise the need to recognise not just the level of authorisation of the archive but also crucially the intentionality of the participation, of moving from collecting and sharing and the 'unintentional archive' to actively constituting the archive as an action and direct intervention. ${ }^{41}$ The role these archives (from materials and objects relating to historical events to online video documenting contemporary events such as war, revolutions and interactions with the state) play can, following Choudry and Vally, be characterised as recovery, resistance and creative aspiration.

Almost all community-based archives exist either to collect or preserve a history and heritage that is either endangered through neglect or not represented in other, more mainstream and dominant, narratives and heritage processes. This might occur as an act of urgent 'salvage' when a crucial local industry declines or an area is redeveloped and gentrified, and the history and memories of those communities risk being lost because the communities are dispersed and mainstream institutions are apparently not active in collecting their traces. (For instance the South Wales Miners Library was established in the 1970s because of the perception that 'it was as if the written and spoken word of the common miner should not be saved, even for posterity' by mainstream bodies. ${ }^{42}$ ) Where there are redevelopment and gentrification schemes, community activists have widely initiated oral history and participatory archives projects to counter fears that communities would be destroyed and memories of their lives would be lost, and as part of a strategy to resist or at least influence the changes ${ }^{43}$ Where people (over generations) have been forced as refugees out of their homes, communities and lands, the 'fever' associated with the activity of participating in community-based archiving can be a crucial component of seeking to retain memories of those homes and communities, which may have long since been destroyed and physically erased. ${ }^{44}$

In some cases it is not just individual and community memories that are under threat but entire cultures and languages. The threats to, and actual disappearance of, indigenous languages and cultures under pressure from colonialism and globalism provoke a number of community-based responses in physical and online forms, which seek to preserve and, in some cases, identify and repatriate cultural heritage for the future use and revitalisation of the communities to which this heritage primarily belongs. ${ }^{45}$ Where there is a lack of archives and material culture relating to a particular culture or community in mainstream heritage and archive bodies, and the nature of many of the surviving material traces of for instance marginalised minority ethnic or LGBTQ (lesbian, gay, bisexual, transgender and queer) groups or cultures and interests peripheral to mainstream collecting is ephemeral, there is is an urgent task to collect and preserve those traces 
before they disappear. Despite the appearance of digital abundance, such digital traces may be even more fragile and susceptible to lose without an active approach to their salvage and preservation. Crucially, the ephemeral condition of the material preserved (a flyer or ticket, a message board or unmaintained web page) does not mean that the emotional resonance of these unique traces of community memories and cultures is not strong and powerfully effective and that in these circumstances these traces, and hence the act of preserving them, are not extremely significant. ${ }^{46}$ In the most severe circumstances, as in the case of the Egyptian activist archive 858 , the act of salvage, documentation and preservation is intended to counter the attempts by the state or other actors to destroy the material, memories and evidence of events of the recent past, putting pressure on platforms like YouTube and Facebook to take down and remove 'subversive' materials. ${ }^{47}$

Whatever the undoubted significance of rescue and preservation, activist participatory community-based archive initiatives are rarely solely about preservation. The collection of material is associated with active use and engagement and knowledge production, often with contemporary strategies of resistance, activist learning and building of collective solidarities. Ruth Frow explained that she and her husband had spent their lives collecting and creating the Working Class Movement Library out of their own collections and in their own home as a matter of political conviction, 'We were basically socialist propagandists rather than historians or librarians. ${ }^{48}$ Such work, knowledge production and resistance can take many forms. The desired impact might be in to mobilise solidarities, emphasising shared identities and activating a strategic essentialism via an engagement with past histories of struggle or experience, or a deeper learning from past struggles to inform contemporary campaigning. ${ }^{49}$ Some interventions might take the form of seeking to challenge dominant narratives and provide resources for the provision of education materials, for instance addressing the history of the presence of people of African heritage in Britain or of South Asians in America, including their achievements and struggles. ${ }^{50}$ Such educational work might aim to transform the 'heritage' and authorised heritage discourse for all, and more specifically - as an act of reparative history - to provide 'an experience to uplift and inspire', addressing the individual and collective damage arising from not being represented, what Caswell refers to as symbolic annihilation, in national and societal narratives. ${ }^{51}$

In other cases, the archive might be used to intervene in public debates, aim to change policy, challenge discrimination, or document and provide tools for accountability for human rights abuses, denial of rights and killing. Thus those running LGBTQ archives have sought to address the memory and lack of commemoration of the traumas of loss and discrimination; ${ }^{52}$ participants in the Mental Health Archive attempted to intervene in the representation and understanding of the lived experience of mental health issues $;{ }^{53}$ and archivists working on participatory initiatives like A People's Archive of Police Violence in Cleveland seek to document instances of police violence to support justice and accountability and as part of a strategy in which 'the Archive identifies and unpacks systems of oppression while also analyzing the narratives that help to legitimize and hold these institutions in place'. ${ }^{54}$ Similarly the collaborative, user-generated visual human rights Syrian Archive places collecting, preserving and using 'visual documentation of human rights violations in Syria' at the heart of its mission, aiming 'to preserve data as a digital memory, to establish a verified database of human rights violations, and 
to act as an evidence tool for legally implementing justice and accountability as concept and practice in Syria'. 55

While activist participatory archives engage in recovery and salvage, and use the past as a resource and a tool for intervening in the present, these archives are also a resource for imagining and aspiring to different futures from present and past realities. If 'another world is possible' then the 'imaginative archive' can be the place for 'straining to hear the voices that have never been heard, the attachments that cannot be given meaning, and the utopian desire for another future grounded in a different past'. ${ }^{56}$ These 'future archives' and 'future histories ${ }^{57}$ can be places of dreams and imagination, where 'migrant groups' and others can 'engage in imaginative and creative work to form new collective memories' and the archive becomes 'an active aspiration, a tool for reworking desires and memories, part of a project for sustaining cultural identities'. ${ }^{58}$ These archives concerned with the traces of the past but always engaged with 'in the light of the present and the future' can be places of utopian aspiration and imagination as well as subversion and challenge. ${ }^{59}$ While such partial traces allow for the 'limits on the truth claims of the narratives that we construct', they also produce 'the conditions of possibility for the construction of alternative narratives, which have similar claims to truth', thus lending themselves to 'the recognition of past suffering and the creation of futures of hope'. ${ }^{60}$

Appadurai describes digital diasporic archives as spaces 'for the production of anticipated memories' and 'conscious sites of debate and desire'. ${ }^{61}$ Building on these understandings and the experience of her work with the South Asian American Digital Archive, Caswell identifies the role of participatory community-based archives in providing space for shared and collective 'archival imaginaries', a place to 'reimagine the future' of what might have been, of what should have been preserved and might be in future. ${ }^{62}$ The activist perspective of May Day rooms and their holdings is one of 'an active social resource more than a repository; a place where . . the future can be produced more than the past contemplated'. ${ }^{63}$ Those activist archives documenting communities' experience of violence, forced exile and war are as much about looking towards a more just future as they are about the trauma and injustices of the past and present.

\section{Conclusion}

As noted earlier, we embrace the archival multiverse's understanding towards thinking about archives. This approach embraces a plurality of perspectives and practices around archives, community archives and participatory archives in which co-existence is sought without recourse to a centring force. Categorisation debates continue within academic discourse and professional circles, but it is vital to acknowledge the limited vantage point from which assertions are made and the archive ecosystem is viewed. In any attempt to categorise, the dangers of leaning on reductive definitions that ultimately subjugate must be carefully considered and worked through. In a desire to be inclusive, and 'make room' within the professional vantage point, we must continually question the structures of authority within the house we have built, and guard against believing or assuming that all should fit under our roof. The aim here is to acknowledge this tension as we seek to highlight the motivation and objective variety within the so-called activist participatory communities. From recovery to resistance, to creative aspiration these communities 
engage in archiving endeavours for a multiplicity of purposes, always existing and already on their own terms.

\section{Bibliography}

Appadurai, A., Archive and Aspiration. In J. Brouwer and A. Mulder (eds), Information is Alive, V2_Publishing and NAI Publishers, 2003, 14-25.

Archives Task Force. Listening to the Past, Speaking to the Future, Museums, Libraries and Archives Council, 2004.

Baker, S. (ed.), Preserving Popular Music Heritage: do-it-yourself, do-it-together, Routledge, 2015.

Baker, S. and J. Collins, Popular Music Heritage, Community Archives and the Challenge of Sustainability, International Journal of Cultural Studies, 20 (5), 2017, 476-91.

Baker, S. and J. Collins, Sustaining Popular Music's Material Culture in Community Archives and Museums, International Journal of Heritage Studies, 21 (10), 2015, 983-96.

Basu, P. and F. De Jong, Utopian Archives, Decolonial Affordances: introduction to special issue, Social Anthropology/Anthropologie Sociale, 24 (1), 2016, 5-19.

Carter, E., 'Setting the Record Straight': the creation and curation of archives by activist communities; a case study of activist responses to the regeneration of Elephant and Castle, South London, Archives and Records, 38 (1), 2017, 27-44.

Caswell, M., Seeing Yourself in History: community archives and the fight against symbolic annihilation, The Public Historian, 36 (4), 2014, 26-37.

Caswell, M., Toward a Survivor-Centered Approach to Records Documenting Human Rights Abuse: lessons from community archives, Archival Science, 14, no. 3-4, 2014, 307-22.

Caswell, M. and S. Mallick, Collecting the Easily Missed Stories: digital participatory microhistory and the South Asian American Digital Archive, Archives and Manuscripts, 42 (1), 2014, 73-86.

Choudry, A., Learning Activism: The Intellectual Life of Contemporary Social Movements, University of Toronto Press, 2015.

Choudry, A. and S. Vally, Learning From, In, and With Independent Community and Activist Archives: the past in our present and future, Education as Change, 22 (2), 2018, 1-9.

Collins, J., Doing-it-Together: public history-making and activist archiving in online popular music community archives. In S. Baker (ed.), Preserving Popular Music Heritage: do-ityourself, do-it-together, Routledge, 2015, 77-90.

Community Archives Development Group, The Impact of Community Archives, 2007, www.aughty.org/pdf/impact_comm_archives1.pdf. 
Cooper, F., Colonialism in Question: theory, knowledge, history, University of California Press, 2005.

Crooke, E., Museums and Community: ideas, issues and challenges, Routledge, 2007.

Cvetkovich, A., An Archive of Feelings: trauma, sexuality, and lesbian public cultures, Duke University Press Books, 2003.

De Kosnik, A., Rogue Archives: digital cultural memory and media fandom, MIT Press, 2016.

Denison, T. and L. Stillman, Academic and Ethical Challenges in Participatory Models of Community Research, Information, Communication and Society, 15 (7), 2012, 1037-54.

Doumani, B., Archiving Palestine and the Palestinians: the patrimony of Ihsan Nimr, Journal of Palestine Studies, 36, 2009, 3-12.

Drake, J. M., Seismic Shifts: on archival fact and fictions, Sustainable Futures, 20 August 2018, https://medium.com/community-archives/seismic-shifts-on-archival-fact-and-fictions6db4d5c655ae..

Eichhorn, K., DIY Collectors, Archiving Scholars, and Activist Librarians: legitimizing feminist knowledge and cultural production since 1990, Women's Studies, 39 (6), 2010, 622-46.

Ernst, W., Digital Memory and the Archive, University of Minnesota Press, 2013.

Ersoy, A., The Impact of Co-Production: from community engagement to social justice, Policy Press, 2017.

Eveleigh, A., Crowding out the Archivist? Implications of online user participation for archival theory and practice, $\mathrm{PhD}$ thesis, University College London, 2015, http://discovery.ucl.ac.uk/1464116/1/Eveleigh-AMM-PhD-2015.pdf.

Faulkhead, S., L. Iacovino, S. McKemmish and K. Thorpe, Australian Indigenous Knowledge and the Archives: embracing multiple ways of knowing and keeping, Archives and Manuscripts, 38 (1), 2010, 27-50.

Featherstone, M., Archive, Theory, Culture and Society, 23 (2-3), 2006, 591-6.

Ferguson, J., Transnational Topographies of Power: beyond 'the state' and 'civil society' in the study of African politics, Occasional Paper of the Roskilde University, International Development Studies, 19 1998, 45-71.

Finnegan, R. (ed.), Participating in the Knowledge Society: researchers beyond the university walls, Palgrave Macmillan, 2005.

Flinn, A., Community Histories, Community Archives: some opportunities and challenges, Journal of the Society of Archivists 28 (2), 2007, 151-76. 
Flinn, A. and B. Alexander, 'Humanizing an Inevitably Political Craft': introduction to the special issue on archiving activism and activist archiving, Archival Science, 15 (4), 2015, 32935 .

Flinn, A. and A. Sexton, Research on Community Heritage: moving from collaborative research to participatory and co-designed research practice. In S. Watson, A. J. Barnes and K. Bunning (eds), A Museum Studies Approach to Heritage, Routledge, 2018, 625-39.

Flinn, A., M. Stevens and E. Shepherd, Whose Memories, Whose archives?: independent community archives, autonomy, and the mainstream, Archival Science 9 (1) 2009, 71-86.

Francis, H. and S. Williams, Do Miners Read Dickens? Origins and progress of the South Wales Miners Library, 1973-2013, Parthian, 2013.

Frow, R., Edmund Frow 1906-1997: the making of an activist, Working Class Movement Library, 1999.

Giannachi, G., Archive Everything: mapping the everyday, MIT Press, 2016.

Gilliland, A. and A. Flinn, Community Archives: what are we really talking about? In L. Stillman, A. Sabiescu and N. Memarovic (eds), Nexus, Confluence, and Difference: community archives meets community informatics; Prato CIRN Conference Oct 28-30 2013, Monash University, 2013, https://www.monash.edu/_data/assets/pdf_file/0007/920626/gilliland_flinn_keynote.pdf.

Gilliland, A. and S. McKemmish, The Role of Participatory Archives in Furthering Human Rights, Reconciliation and Recovery, Atlanti, 24, 2014, 79-88.

Gilliland, A. J., S. McKemmish and A. J. Lau, Research in the Archival Multiverse, Monash University Press, 2016.

Hall, S., Constituting an Archive, Third Text, 15 (54), 2001, 89-92.

Hall, S., Whose Heritage? Un-settling 'the heritage', re-imagining the post-nation. In J. Littler and R. Naidoo (eds), The Politics of Heritage: the legacies of 'race', Routledge, 2005, 23-35.

Hemmings, C., Considering Emma Goldman: feminist political ambivalence \& the imaginative archive, Duke University Press, 2018.

Hopkins, I., Places from Which to Speak, Journal of the Society of Archivists, 29 (1), 2008, 83109.

Huvila, I., Participatory Archive: towards decentralised curation, radical user orientation, and broader contextualisation of records management, Archival Science, 8 (1), March 2008, 15-36, https://doi.org/10.1007/s10502-008-9071-0.

Iacovino, L., Shaping and Reshaping Cultural Identity and Memory: maximising human rights through a participatory archive, Archives and Manuscripts, 43 (1), 2015, 29-41. 
Ishmael, H. J. M. and R. Waters, Archive Review: the Black Cultural Archives, Brixton, Twentieth Century British History, 28 (3), 2017, 465-73.

Jura Consultants, Community Archives and the Sustainable Communities Agenda, 2009.

Lindqvist, S., Dig Where You Stand, Oral History, 7 (2), 1979, 24-30.

Linn, M. S., Living Archives: a community-based language archive model, Language Documentation and Description, 12 (1), 2014, 53-67.

Long, P., Really Saying Something? What do we talk about when we talk about popular music heritage, memory, archives and the digital? In S. Baker (ed.), Preserving Popular Music Heritage: do-it-yourself, do-it-together, Routledge, 2015.

Merrifield, A.,The Amateur: the pleasure of doing what you love, Verso, 2018.

Moore, N., Weaving Archival Imaginaries. In N. Moore, A. Salter, L. Stanley and M. Tamboukou (eds), The Archive Project: archival research in the social sciences, Routledge, 2016.

Moosa-Mitha, M., Situating Anti-Oppressive Theories within Critical and Difference Centred Perspectives. In L. Brown and S. Strega, Research as Resistance: critical indigenous and antioppressive approaches, Canadian Scholars' Press, 2005, 37-72

Nestle, J., The Will to Remember: the Lesbian Herstory Archives of New York, Feminist Review, 34 (1), 1990, 86-94.

Omowale, Y., We Already Are, Sustainable Futures, 3 September 2018, https://medium.com/community-archives/we-already-are-52438b863e31.

Radjy, A.-H., An Internet Archive Seeks to Rekindle the Egyptian Revolution's Spirit, The Atlantic, 25 January 2018, https://www.theatlantic.com/international/archive/2018/01/aninternet-archive-rekindles-the-egyptian-revolutions-spirit/551489/.

Sexton, A., Archival Activism and Mental Health: being participatory, sharing control and building legitimacy, PhD Thesis, University College London, 2016, http://discovery.ucl.ac.uk/1474368/1/A\%20Sexton\%20Thesis\%20With\%20Corrections.pdf.

Shilton, K. and R. Srinivasan, Participatory Appraisal and Arrangement for Multicultural Archival Collections, Archivaria 63 (1), 2007, 87-101.

Sivanandan, A., Race and Resistance: the IRR story, Race \& Class, 50 (2), 2008, 1-30.

Smith, L., Uses of Heritage, Routledge, 2006.

Strega, S., The View from the Poststructural Margins: epistemology and methodology reconsidered. In Brown and Strega, Research as Resistance, 199-236.

Sturken, M., AIDS Activist Legacies and the Gran Fury of the Past/Present, On the Subject of Archives, 9 (1-2), 2012, http://hemisphericinstitute.org/hemi/en/e-misferica-91/sturken. 
Theimer, K., Building Participatory Archives, Archives Next, 22 August 2010, http://archivesnext.com/?p=1536.

Tsing, A., The Global Situation, Cultural Anthropology, 15 (3), 2000, 327-60.

X, A., T. Campbell and M. Stevens, Love and Lubrication in the Archives, or Rukus!: a black queer archive for the United Kingdom, Archivaria, 68, 2010, 271-94.

Yakel, E., Balancing Archival Authority with Encouraging Authentic Voices to Engage with Records. In K. Theimer (ed.), A Different Kind of Web: new connections between archives and our users, Society of American Archivists, 2011.

\footnotetext{
${ }^{1}$ A. J. Gilliland, S. McKemmish and A. J. Lau, Research in the Archival Multiverse, Monash University Press, 2016.

${ }^{2}$ K. Theimer, Building Participatory Archives, Archives Next, 22 August 2010, http://archivesnext.com/?p=1536; A. Eveleigh, Crowding out the Archivist? Implications of online user participation for archive theory and practice, $\mathrm{PhD}$ thesis, University College London, 2015, http://discovery.ucl.ac.uk/1464116/1/Eveleigh-AMM-PhD-2015.pdf; A. Flinn and A. Sexton, Research on Community Heritage: moving from collaborative research to participatory and codesigned research practice. In S. Watson, A. J. Barnes and K. Bunning (eds), A Museum Studies Approach to Heritage, Routledge, 2018, 625-39; A. Gilliland and S. McKemmish, The Role of Participatory Archives in Furthering Human Rights, Reconciliation and Recovery, Atlanti, 24, 2014, 79-88.

${ }^{3}$ A. Ersoy, The Impact of Co-Production: from community engagement to social justice, Policy Press, 2017.

${ }^{4}$ See Chapter 14.

${ }^{5}$ Ersoy, The Impact of Co-Production.

${ }^{6}$ Archives Task Force, Listening to the Past, Speaking to the Future, Museums, Libraries and Archives Council, 2004; Community Archives Development Group, The Impact of Community Archives, June 2007, www.aughty.org/pdf/impact_comm_archives1.pdf; Jura Consultants, Community Archives and the Sustainable Communities Agenda, 2009.

${ }^{7}$ A. Flinn, Community Histories, Community Archives, 151-76; I. Hopkins, Places from Which to Speak, Journal of the Society of Archivists, 29 (1), 2008, 83-109; Flinn, Stevens and Shepherd, Whose Memories, Whose Archives?, 71-86.

${ }^{8}$ R. Finnegan (ed.), Participating in the Knowledge Society: researchers beyond the university walls, PalgraveMacmillan, 2005.

${ }^{9}$ A. Merrifield, The Amateur: the pleasure of doing what you love, Verso, 2018, 15.

${ }^{10}$ Archives Task Force, Listening to the Past, Speaking to the Future.

${ }^{11}$ See the mediated definition provided by Benoit and Roeschley in Chapter 14.

${ }^{12}$ Community Archives and Heritage Group, What is a Community Archive? www.communityarchives.org.uk/content/about/what-is-a-community-archive; Community Archives and Heritage Group, Vision Statement, www.communityarchives.org.uk/content/about/history-and-purpose.

${ }^{13}$ N. Moore, Weaving Archival Imaginaries. In N. Moore, A. Salter, L. Stanley and M. Tamboukou (eds), The Archive Project: archival research in the social sciences, Routledge, 2016.

${ }^{14} \mathrm{~W}$. Ernst, Digital Memory and the Archive, University of Minnesota Press, 2013, 82.

${ }^{15}$ G. Giannachi, Archive Everything: mapping the everyday, MIT Press, 2016.

${ }^{16}$ E. Crooke, Museums and Community: ideas, issues and challenges, Routledge, 2007.

${ }^{17}$ A. Gilliland and A. Flinn, Community Archives: what are we really talking about? In L. Stillman, A. Sabiescu and N. Memarovic (eds), Nexus, Confluence, and Difference: community archives meets community informatics; Prato CIRN Conference Oct 28-30 2013, Monash University, 2013, https://www.monash.edu/_data/assets/pdf_file/0007/920626/gilliland_flinn_keynote.pdf.

${ }^{18}$ J. M. Drake, Seismic Shifts: on archival fact and fictions, Sustainable Futures, 20 August 2018, https://medium.com/community-archives/seismic-shifts-on-archival-fact-and-fictions-6db4d5c655ae.

${ }^{19}$ Drake, Seismic Shifts; J. Ferguson, Transnational Topographies of Power: beyond 'the state' and 'civil society' in the study of African politics, Occasional Paper of the Roskilde University, International Development Studies, 19
} 
1998, 45-71; A. Tsing, The Global Situation, Cultural Anthropology, 15 (3), 2000, 327-60; F. Cooper, Colonialism in Question: theory, knowledge, history, University of California Press, 2005.

${ }^{20}$ Gilliland and Flinn, Community Archives.

${ }^{21}$ Y. Omowale, We Already Are, Sustainable Futures, 3 September 2018, https://medium.com/communityarchives/we-already-are-52438b863e31.

${ }^{22}$ A. Flinn and B. Alexander, 'Humanizing an Inevitably Political Craft': introduction to the special issue on archiving activism and activist archiving, Archival Science, 15 (4), 2015, 329-35.

${ }^{23}$ K. Shilton and R. Srinivasan, Participatory Appraisal and Arrangement for Multicultural Archival Collections, Archivaria, 63, 2007, 87-101.

${ }^{24}$ Eveleigh, Crowding out the Archivist?; E. Yakel, Balancing Archival Authority with Encouraging Authentic Voices to Engage with Records. In Theimer (ed.), A Different Kind of Web.

${ }^{25}$ I. Huvila, Participatory Archive: towards decentralised curation, radical user orientation, and broader contextualisation of records management, Archival Science, 8 (1), 2008, 15-36.

${ }^{26}$ See for example S. Faulkhead, L. Iacovino, S. McKemmish and K. Thorpe, Australian Indigenous Knowledge and the Archives: embracing multiple ways of knowing and keeping, Archives and Manuscripts, 38 (1), 2010, 27-50; Gilliland and McKemmish, The Role of Participatory Archives; M. Caswell, Toward a Survivor-Centered Approach to Records Documenting Human Rights Abuse: lessons from community archives, Archival Science, 14, no. 3-4, 2014, 307-22; L. Iacovino, Shaping and Reshaping Cultural Identity and Memory: maximising human rights through a participatory archive, Archives and Manuscripts, 43 (1), 2015, 29-41.

${ }^{27}$ A. Sexton, Archival Activism and Mental Health: being participatory, sharing control and building legitimacy, $\mathrm{PhD}$ Thesis, University College London, 2016, http://discovery.ucl.ac.uk/1474368/1/A\%20Sexton\%20Thesis\%20With\%20Corrections.pdf.

${ }^{28}$ T. Denison and L. Stillman, Academic and Ethical Challenges in Participatory Models of Community Research, Information, Communication and Society, 15 (7), 2012, 1037-54.

${ }^{29}$ M. Moosa-Mitha, Situating Anti-Oppressive Theories within Critical and Difference Centred Perspectives. In L. Brown and S. Strega, Research as Resistance: critical indigenous and anti-oppressive approaches, Canadian Scholars' Press, 2005, 37-72.

${ }^{30}$ S. Strega, The View from the Poststructural Margins: epistemology and methodology reconsidered. In Brown and Strega, Research as Resistance, 199-236.

${ }^{31}$ Gilliland and McKemmish, The Role of Participatory Archives.

${ }^{32}$ S. Hall, Constituting an Archive, Third Text, 15 (54), 2001, 89-92.

${ }^{33}$ Omowale, We Already Are.

${ }^{34}$ L. Smith, Uses of Heritage, Routledge, 2006; M. Caswell, Seeing Yourself in History: Community Archives and the Fight Against Symbolic Annihilation, The Public Historian, 36 (4), 2014, $26-37$.

${ }^{35}$ History Workshop, www.historyworkshop.org.uk/.

${ }^{36}$ S. Lindqvist, Dig Where You Stand, Oral History, 7 (2), 1979, 24-30.

${ }^{37}$ A. Choudry, Learning Activism: the intellectual life of contemporary social movements, University of Toronto Press, 2015.

${ }^{38}$ A. Choudry and S. Vally, Learning From, In, and With Independent Community and Activist Archives: the past in our present and future, Education as Change, 22 (2), 2018, 2.

${ }^{39}$ S. Baker (ed.), Preserving Popular Music Heritage: do-it-yourself, do-it-together, Routledge, 2015; P. Long, Really Saying Something? What do we talk about when we talk about popular music heritage, memory, archives and the digital? In Baker (ed.), Preserving Popular Music Heritage; J. Collins, Doing-it-Together: public history-making and activist archiving in online popular music community archives. In Baker (ed.), Preserving Popular Music Heritage; A. De Kosnik, Rogue Archives: digital cultural memory and media fandom, MIT Press, 2016.

${ }^{40}$ Hall, Constituting an Archive.

${ }^{41}$ S. Baker and J. Collins, Sustaining Popular Music's Material Culture in Community Archives and Museums, International Journal of Heritage Studies, 21 (10), 2015, 983-96; S. Baker and J. Collins, Popular Music Heritage, Community Archives and the Challenge of Sustainability, International Journal of Cultural Studies, 20 (5), 2017, 476-91.

${ }^{42}$ H. Francis and S. Williams, Do Miners Read Dickens? Origins and progress of the South Wales Miners Library, 1973-2013, Parthian, 2013.

${ }^{43}$ See for instance Heygate Was Home, http://heygatewashome.org/; E. Carter, Setting the Record Straight: the creation and curation of archives by activist communities; a case study of activist responses to the regeneration of Elephant and Castle, South London, Archives and Records, 38 (1), 2017, 27-44. 
${ }^{44}$ B. Doumani, Archiving Palestine and the Palestinians: the patrimony of Ihsan Nimr, Journal of Palestine Studies, 36, 2009, 3-12.

${ }^{45}$ M. S. Linn, Living Archives: a community-based language archive model, Language Documentation and Description, 12 (1), 2014, 53-67.

${ }^{46}$ Caswell, Setting the Record Straight; M. Caswell and S. Mallick, Collecting the Easily Missed Stories: digital participatory microhistory and the South Asian American Digital Archive, Archives and Manuscripts, 42 (1), 2014, 73-86; Baker and Collins, Sustaining Popular Music's Material Culture.

${ }^{47}$ A.-H. Radjy, An Internet Archive Seeks to Rekindle the Egyptian Revolution's Spirit, The Atlantic, 25 January 2018, https://www.theatlantic.com/international/archive/2018/01/an-internet-archive-rekindles-the-egyptianrevolutions-spirit/551489/.

${ }^{48}$ R. Frow, Edmund Frow 1906-1997: the making of an activist, Working Class Movement Library, 1999.

${ }^{49}$ Choudry, Learning Activism; Caswell, Toward a Survivor-Centered Approach; J. Nestle, The Will to Remember: the Lesbian Herstory Archives of New York, Feminist Review, 34 (1), 1990, 86-94; A. Sivanandan, Race and Resistance: the IRR story, Race \& Class, 50 (2), 2008, 1-30; K. Eichhorn, DIY Collectors, Archiving Scholars, and Activist Librarians: legitimizing feminist knowledge and cultural production since 1990, Women's Studies, 39 (6), 2010, 622-46.

${ }^{50}$ H. J. M. Ishmael and R. Waters, Archive Review: the Black Cultural Archives, Brixton, Twentieth Century British History, 28 (3), 2017, 465-73; Caswell and Mallick, Collecting the Easily Missed Stories.

${ }^{51}$ Caswell, Seeing Yourself in History; Ishmael and Waters, Archive Review; S. Hall, Whose Heritage? Un-settling 'the heritage', re-imagining the post-nation. In J. Littler and R. Naidoo (eds), The Politics of Heritage: the legacies of 'race', Routledge, 2005, 23-35.

${ }^{52}$ X. Ajamu, T. Campbell and M. Stevens, Love and Lubrication in the Archives, or Rukus!: a black queer archive for the United Kingdom, Archivaria, 68, 2010, 271-94; A. Cvetkovich, An Archive of Feelings: trauma, sexuality, and lesbian public cultures, Duke University Press Books, 2003; M. Sturken, AIDS Activist Legacies and the Gran Fury of the Past/Present, On the Subject of Archives, 9 (1-2), 2012, http://hemisphericinstitute.org/hemi/en/emisferica-91/sturken.

${ }^{53}$ Sexton, Archival Activism and Mental Health.

${ }^{54}$ A People's Archive of Police Violence in Cleveland, Principles, www.archivingpoliceviolence.org/principles.

${ }_{55}^{55}$ Syrian Archive, About, https://syrianarchive.org/en/about.

${ }^{56} \mathrm{C}$. Hemmings, Considering Emma Goldman: feminist political ambivalence \& the imaginative archive, Duke University Press, 2018.

${ }^{57}$ See variously the Future Archive Blog, https://thefuturearchiveblog.wordpress.com/, and Future Histories, www.futurehistories.org.uk/.

${ }_{58}^{58}$ M. Featherstone, Archive, Theory, Culture and Society, 23 (2-3), 2006, 591-6.

${ }^{59}$ Hall, Constituting an Archive.

${ }^{60}$ P. Basu and F. De Jong, Utopian Archives, Decolonial Affordances: introduction to special issue, Social Anthropology/Anthropologie Sociale, 24 (1), 2016, 5-19.

${ }^{61}$ A. Appadurai, Archive and Aspiration. In J. Brouwer and A. Mulder (eds), Information is Alive, V2_Publishing and NAI Publishers, 2003, 14-25.

${ }^{62}$ Caswell, Seeing Yourself in History.

${ }^{63}$ Mayday Rooms, Archives, http://maydayrooms.org/archives/. 